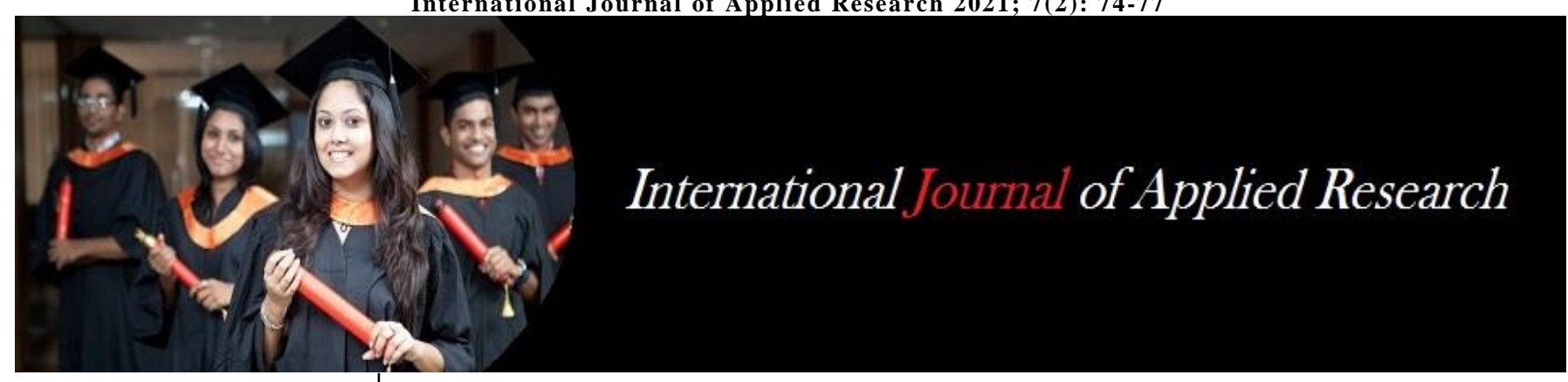

ISSN Print: 2394-7500

ISSN Online: 2394-5869

Impact Factor: 8.4

IJAR 2021; 7(2): 74-77

www.allresearchjournal.com

Received: 04-12-2020

Accepted: 06-01-2021

Damesh Gangber

Research Scholar,

Mats School of Arts and

Humanities, Mats

University Raipur,

Chhattisgarh, India

Dr. Shaista Ansari

Asst. Professor,

Mats School of Arts and

Humanities, Mats University

Raipur, Chhattisgarh, India

Dr. Anshu Shrivastava

Asst. Professor,

Mats School of Arts and

Humanities, Mats University

Raipur, Chhattisgarh, India

Corresponding Author:

Damesh Gangber

Research Scholar,

Mats School of Arts and

Humanities, Mats

University Raipur,

Chhattisgarh, India

\section{Relationship between career aspirations and self- confidence among higher secondary students}

\author{
Damesh Gangber, Dr. Shaista Ansari and Dr. Anshu Shrivastava
}

DOI: https://doi.org/10.22271/allresearch.2021.v7.i2b.8243

\begin{abstract}
The major determinant of career aspiration, self-confidence plays a major role in developing career orientations among higher secondary students. The present descriptive survey research conducted on 50 higher secondary students (25 male and 25 female) studying in CGBSE affiliated government school, is intended to explore the relationship between career aspiration and self-confidence among higher secondary students. After analysis and interpretation of data using descriptive and inferential statistics techniques, it was found that majority of the students have low levels of career aspirations and average level of self-confidence. Significant correlation was found between career aspirations and selfconfidence of higher secondary students. Career aspiration of female students were higher than the male while male students were having higher self-confidence than the female. The findings of the study indicate the need for develop career aspirations and enhancing self-confidence among higher secondary students by providing conductive atmosphere for learning, setting realistic and challenging goals, etc. It is also recommended that career guidance programs should be organized systematically in institutions to augment the career aspiration of higher secondary students.
\end{abstract}

Keywords: adolescents, gender, career aspirations, self-confidence, higher secondary students

\section{Introduction}

Adolescence is a time when teenagers develop certain aspirations regarding their educational and future careers. During adolescence, aspirations are especially important because they allow teenagers to evaluate the degree to which various choices help or hinder their chances of attaining desired goals. Education is a process and kind of activity for human beings. It is a continuous effort to develop all capacities of the students to control their neighboring environment and to fulfill their needs. Today we live in a society characterized by technological advancements, knowledge explosion, and globalization. Competition is an essential consequence in such a scenario. Now the process of education has become the most important factor which determines one's destiny. Pinpointing the goal, selecting appropriate and effective strategies to achieve it, and working out the strategies without fail is crucial in the process of education.

Aspirations play an important role in career decisions because they reflect the goals and intentions that influence individuals toward a particular course of action. Career aspirations are the desire and intention to pursue an occupation or a particular position within an occupation. Aspiration as the success and strong desire to something, the aim of such desire. British Dictionary defines Career aspirations are defined as a cluster of needs, motives, and behavioral intentions that individuals articulate concerning different career field options.

Self-confidence is the process of knowledge that we can do something and do it well. Selfconfidence gained from at firsthand knowledge of the task for knowing your strengths and weakness, using your skill for a situation, and conforming as fast as situation and unfolds. A student who shows self-confidence knows they take the task to master difficult situations and they don't afraid of failure. Self-confidence is an outlook that permits individuals to have a positive and realistic attitude of themselves and their situations.

\subsection{Review of related literature}

Pattanayak \& Naik (2014) ${ }^{[10]}$ investigated the Career aspirations and career development barriers of trial students. The results found that aspirations of tribal students are influenced by gender roles, socialization, parental expectations, teacher attitudes, as well as the 
gendered occupational landscape in which they exist. Obura \& Ajowi (2012) [9] investigated the gender and students' perceptions of career aspiration in secondary schools. Finding results indicate that there was a gender disparity in the career aspirations of secondary school students. There was a positive correlation between career aspiration and gender. Khan (2014) ${ }^{[7]}$ studied the impact of parent-child relationship on social maturity and self- confidence of the students of higher secondary schools of. Findings revealed that there is no significant relationship between the parentchild relationship on social maturity and self- confidence of the higher secondary students. Gurubasappa (2009) studied intelligence and self-confidence as correlates of the academic achievement of secondary school students. The findings results indicate that highly intelligent students 2 achieved high self-confidence in school i.e. the academic achievement of students was certainly influenced by psychological factors like intelligence and self-confidence. There was a positive/high significant correlation of academic achievement with intelligence and self-confidence of secondary school students.

\subsection{Significance of the study}

The senior secondary level is the most crucial period when career decisions are taken by adolescents. Adolescence would be an ideal time to study the career development of young men and women, as many changes occur during this time that strongly influence the formation of career aspirations and preferences. The period of higher secondary education is a turning point in the life of students; they make career choices during this period of study. Most of the students develop career aspiration based on the information they get regarding various occupation from different sources. They plan for their expectations at this period. Therefore it is worthwhile to study the relationship between career aspiration and self-confidence among higher secondary students.

1.3 Statement of the problem: Relationship between career aspirations and self-confidence among higher secondary students.

\subsection{Objective of the study}

1. To study the level of career aspirations and selfconfidence of higher secondary students.

2. To study the relationship between career aspirations a dind self-confidence of higher secondary students.

3. To find out the significance of gender differences in the career aspirations and self-confidence of higher secondary students.

4. To find out the difference between the career aspirations of secondary school students with high, average and low self-confidence.

\subsection{Hypothesis}

1. There is a significant relationship between the career aspirations and self-confidence of higher secondary students.

2. There is a significant gender differences in the career aspirations and self-confidence of higher secondary students.

3. There is a significant differences in the career aspirations of higher secondary students with high, average and low self-confidence.

\subsection{Delimitations of the study}

. The present study is confined to the higher secondary students of Dhamtari district in Chhattisgarh only.

The study is confined to the higher secondary students of CGBSE affiliated Government school only.

\section{Methodology}

The present study has been conducted through a descriptive survey method in which questionnaires were given to the sample higher secondary students in the study.

\subsection{Population of the study}

In the proposed study, population refers to all the higher secondary students studying in class XII of CGBSE affiliated school of Dhamtari district in Chhattisgarh.

\subsection{Sample of the study}

To conduct the present study the investigator adopted descriptive survey method. The sample for the study consisted of 50 (25 male and 25 female) students selected randomly from various higher secondary students of Dhamtari district in Chhattisgarh.

\subsection{Research Tools used}

Career aspiration scale by Dr. Sarita Anand (2014) and Selfconfidence scale Prof. (Dr.) Madhu Gupta and Ms. Bindiya Lakhani (2018) ${ }^{[4]}$ were used to collected data pertaining to career aspirations and self-confidence of higher secondary students.

\subsection{Statistical Techniques}

For the purpose of statistical analysis of data, following statistical technique were employed.

Descriptive Statistics: Mean and Standard Deviation.

Inferential Statistics: Pearson's coefficient of correlation tTest and ANOVA.

\section{Results}

3.1 Level of career aspirations and self-confidence of higher secondary students

Table 1: Showing level of career aspirations and self-confidence of higher secondary students.

\begin{tabular}{|c|c|c|c|c|}
\hline \multirow{2}{*}{ Level } & \multicolumn{2}{|c|}{ Career Aspirations } & \multicolumn{2}{c|}{ Self-confidence } \\
\cline { 2 - 5 } & $\mathbf{N}$ & $\mathbf{\%}$ & $\mathbf{N}$ & $\mathbf{\%}$ \\
\hline High & 1 & 2 & 0 & 0 \\
\hline Average & 15 & 30 & 41 & 92 \\
\hline Low & 34 & 68 & 4 & 8 \\
\hline Total & 50 & 100 & 50 & 100 \\
\hline
\end{tabular}




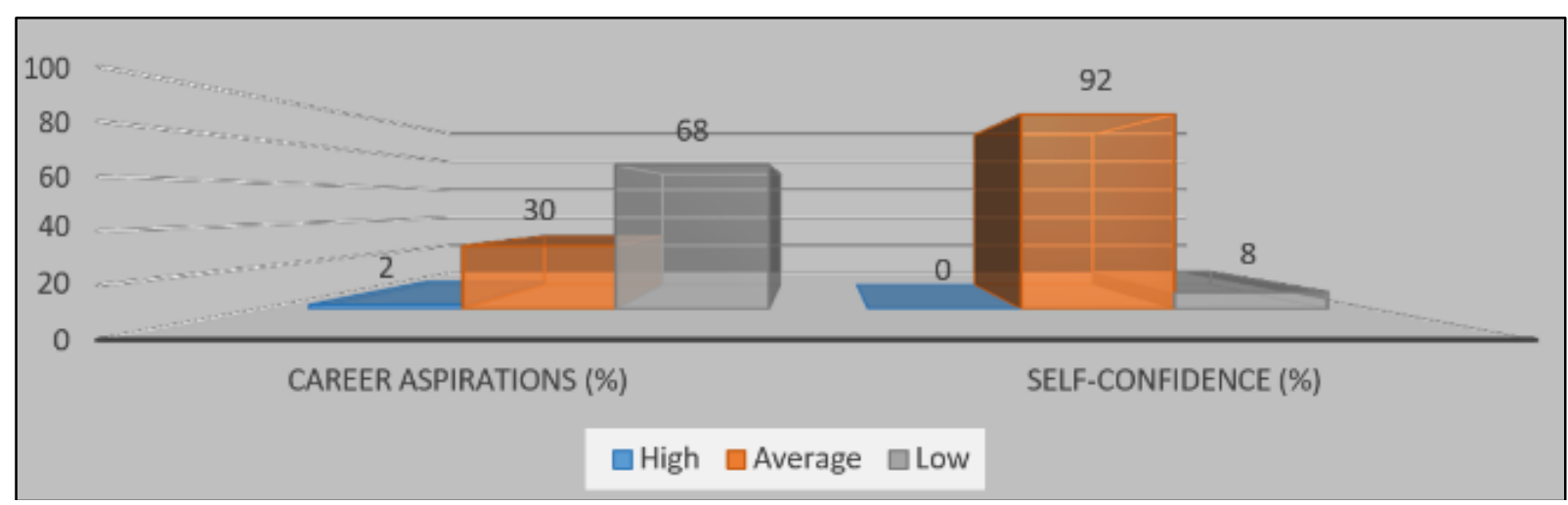

Level of career aspirations and self-confidence of higher secondary students

Table and Figure No.1 shows that the majority of higher secondary students are having low level of career aspirations and average level of self-confidence. Students having high level of career aspirations are very few. Also student having high self-confidence are zero in number.

3.2 Relationship between the career aspirations and selfconfidence of higher secondary students

Table 2: Correlation between career aspirations and self-confidence of higher secondary students

\begin{tabular}{|c|c|c|c|c|}
\hline Sr. No. & Variables & $\mathbf{N}$ & $\mathbf{r}$ & Level of Significance \\
\hline 1. & Career Aspirations & 50 & $0.334^{*}$ & $P<0.05$ \\
\hline 2. & 2. & 50 & & \\
\hline *Correlation is significant at the 0.05 level
\end{tabular}
-

It is depicted from the table 2 that the coefficient of correlation between career aspirations and self-confidence of higher secondary students is 0.334 indicating that the career aspiration and self-confidence of higher secondary students are significantly and positively correlated. It indicates that there is high inverse relationship between career aspirations and self-confidence score which means higher the career aspirations higher will be the score on selfconfidence, hence more confident will be the child.

\subsection{Gender differences in the career aspirations and self- confidence of higher secondary students}

Table 3: Mean and SD for career aspirations and self-confidence of male and female higher secondary students

\begin{tabular}{|c|c|c|c|c|c|}
\hline Source of Variance & Sum of Squares & df & Mean Square & F & Significance \\
\hline Between Groups & 184.320 & 1 & 184.320 & \multirow{2}{*}{0} & \multirow{2}{*}{0.218} \\
\hline Within Groups & 5676.160 & 48 & 118.253 & & \\
\hline Total & 5860.480 & 49 & & & \\
\hline
\end{tabular}

Table 3 clearly depicted that the obtained t-value for career aspirations and self-confidence are significant at 0.05 level. Also the calculated mean shows that career aspirations of female higher secondary students are higher than that of male higher secondary students while on the variable of self-confidence, male higher secondary students excels their female counterparts.

\subsection{Comparison of the career aspirations of higher secondary students in high, average and low self- confidence groups}

Table 4: Showing summary of Analysis of Variance (ANOVA) for difference in career aspirations of higher secondary students with high, average and low self-confidence

\begin{tabular}{|c|c|c|c|c|c|c|}
\hline Variables & Gender & $\mathbf{N}$ & Mean & SD & df & Level of Significance \\
\hline \multirow{2}{*}{ Career aspirations } & Male & 25 & 103.60 & 12.23 & & \multirow{2}{*}{$P<0.05$} \\
\hline & Female & 25 & 107.44 & 9.32 & 48 & \\
\hline \multirow{2}{*}{ Self-confidence } & Male & 25 & 177.28 & 15.93 & 48 & \multirow{2}{*}{$P<0.05$} \\
\hline & Female & 25 & 174.64 & 13.76 & 48 & \\
\hline
\end{tabular}

Table 4 shows that the calculated F-value 1.559 is significant at 0.05 level (i.e., $p<0.05$ ). This implies that there is the statistically significance difference in the mean career aspirations of higher secondary students with high, average and low self-confidence levels.

\subsection{Findings of the study}

1. Findings revealed that the career aspirations of higher secondary students has low level.
2. Findings revealed that the self-confidence of higher secondary students has average level.

3. It is found that there is significant correlation between the career aspirations and self-confidence level of higher secondary students.

4. It is confirmed that there exists significance gender differences in the career aspirations and selfconfidence of higher secondary students.it has been found that female students are having higher career aspirations as compared to the males but the male 
students are having higher levels of self- confidence than their female counterparts.

5. From the analysis it is observed that the career aspirations of higher secondary students in high, average and low self-confidence groups differ significantly from each other.

\section{Conclusion}

Present study was an attempt to find out the relationship between career aspirations and self-confidence of higher secondary students of Dhamtari district in Chhattisgarh. It has been found that majority of the students have low levels of career aspirations and average levels of self-confidence, hence teachers in schools should try to organize more cocurricular activities like drama, role play, debate etc.to expose the hidden talents of the students and to raise their self-confidence level. Allow students to know their strengths and weakness, provide favorable atmosphere for learning in school and home. Provide career and life planning education programs for higher secondary students. Moreover findings of the present study will be helpful for Counsellor, parents and educators by developing a deeper understanding of adolescents career aspirations in order to assist them in the exploration of career options, help them seek career related information and obtain support for their career plans. The suggestions were made based on the finding of the study in order to develop career aspirations and to enhance selfconfidence of higher secondary students.

\section{References}

1 Anand S. Career Aspiration Scale. Agra: National Psychological Corporation, 2014.

2 Ashby JS, Schoon I. Career success: The role of teenage career aspirations, ambition value and gender in predicting adult social status and earnings. Journal of vocational behavior. 2010;77(3):350-360.

3 Definition of career from the Cambridge Dictionary, Cambridge University Press. https://dictionary.cambridge.org/dictionary/english/care er.

4 Gupta M, Lakhani B. Self- Confidence Scale. Agra: National Psychological Corporation 2018.

5 Gurubassapa HD. Intelligence and self-concept as correlates of academic achievement of secondary school students. Edu tracks 2009;8(10):42-43.

6 Hannah JAS, Kahn SE. (The relationship of socioeconomic status and gender to the occupational choices of grade 12 students. Journal of vocational behavior 1989;34(2):161-178.

7 Khan S. A study of impact of parent child relationship on social maturity and self-confidence of the students of higher secondary schools of Durg District. (Doctoral Dissertation, Department of Education, Pt. RSU Raipur Chhattisgarh, India) 2014. Retrieved from: http://shodhganga.inflibnet.ac.in/handle/10603/98453.

8 Koul L. Methodology of Educational Research, New Delhi, Vikas publishing house 1997,

9 Obura CA, Ajowi JO. Gender and students' perceptions of career aspirations in secondary schools Academic Journal of Interdisciplinary Studies 2012;1(2):149-164. Accessed from: http://citeseerx.ist.psu.edu.

10 Pattanayak MB, Naik PK. Career aspirations and career development barriers of trial students in the Salboni block on Jangal Mahal. Journal of International
Academic Research for Multidisciplinary, 2014;2(3):655-668. Accessed from: www.jiarm.com.

11 Rojewski JW. Occupational aspirations: Constructs, meanings, and application. Career development and counseling: Putting theory and research to work 2005, 131-154. 